This is an author produced version of a paper published in Outlook on Agriculture.

This paper has been peer-reviewed but may not include the final publisher proof-corrections or pagination.

Citation for the published paper:

Axel Wolz, Svetlana Golovina, Jerker Nilsson \& Sebastian Hess. (2016)

Reviewing changing institutional conditions for private farming in Russia.

Outlook on Agriculture. Volume: 45, Number: 2, pp 111-116.

http://dx.doi.org/10.1177/0030727016651214.

Access to the published version may require journal subscription.

Published with permission from: SAGE Publishing.

Epsilon Open Archive http://epsilon.slu.se 


\title{
Reviewing changing institutional conditions for private farming in Russia
}

\author{
Axel Wolz*1, Svetlana Golovina ${ }^{2}$, Jerker Nilsson ${ }^{3}$ and Sebastian Hess ${ }^{4}$ \\ ${ }^{1}$ Department of External Environment for Agriculture and Policy Analysis, Leibniz Institute of Agricultural \\ Development in Transition Economies (IAMO), Theodor-Lieser-Str. 2, 06120 Halle (Saale), Germany \\ ${ }^{2}$ Kurgan State Agricultural Academy, Ketovo district, Kurgan region, Russia 641300 \\ ${ }^{3}$ Department of Economics, Swedish University of Agricultural Sciences, P.O. Box 7013, SE-750 07 Uppsala, \\ Sweden \\ ${ }^{4}$ Department of Agricultural Economics, Christian-Albrechts-Universität zu Kiel, Wilhelm-Seelig-Platz 6, 24098 \\ Kiel, Germany \\ *Corresponding author: wolz@iamo.de
}

\begin{abstract}
With independence and the abolition of the Soviet era's planned economy the dominant organisations of agricultural production, i.e. kolkhozes and sovkhozes, had become obsolete. These organisations had to be restructured and family farms, or more generally private farms, were supposed to form the backbone of farm production. However, development since then has been difficult. Based on a literature review, this study reviews and assesses this development in terms of the changing institutional conditions. The Russian government's policies, by interchangeably supporting large-scale farming organisations or private farming, have created uncertainties for private farmers. Russian farmers were once strongly influenced by the mentality from Soviet times, but there are indications that they are gaining strength, possibly as a consequence of a more benevolent political order, more entrepreneurial attitudes and developing organisational arrangements.
\end{abstract}

Keywords: organisation of agricultural production, transition, restructuring, , institution,

\section{Introduction}

After the dissolution of the Soviet Union in 1991, many Western observers believed that private farmers would take over the bulk of agricultural production in Russia. Economists often maintain that private farming is the most competitive model for agricultural production. It is argued that there are no longer any economies of scale in farming once farm size has reached the labour capacity of a family, as further growth of the labour force is inhibited by rising supervision costs (Binswanger et al., 1995; Eastwood et al., 2010). Family governance is efficient due to the small size of the group and its social cohesion, whereby shirking and free-riding is restricted (Pollak, 1985). Hence, large farm operations can be expected to have higher agency costs and not necessarily lower production costs. On this basis, most political advisors favoured private farming in Russian agriculture after the planned economy was replaced by market economy principles (Lerman, 1998). A large proportion of agricultural land and facilities were expected to be converted into private farms (Schmitt, 1993). However, large-scale farms continued to dominate, since many of the former Soviet kolkhozes and sovkhozes were 
transformed into production co-operatives or became investor-owned agricultural enterprises, organised as limited liability companies or open and closed joint stock companies (Uzun, 2008; Ioffe et al., 2012; Golovina et al., 2013).

This study reviews and assesses the institutional development that Russian private farming has encountered to date. The concept of institutions refers to "systems of established and prevalent social rules that structure social interaction" (Hodgson, 2006). Thus the rules, norms and values that are found in the political and social spheres, as well as those in individuals' minds, are institutions. They direct the behaviour of people and the interaction between people. The aim was to explore institutional conditions in connection with the volatile situation of private farming in Russia. At present, the trend appears positive. Private farming is increasing its share in national agricultural production (Table 1). The farms comprise a broad range, from small-scale farms with a workforce of one or two people up to those with more than 1,000 hectares and employing permanent workers.

A number of researchers have investigated why private farming in Russia has not developed as anticipated (e.g. Lerman, 2008; Sutherland, 2008; Wegren, 2014). One explanation concerns how the unfavourable macro-economic situation, particularly during the 1990s, led to a weak bargaining position for private farmers. While output prices stagnated, input prices increased rapidly. The economic risks were high and many private farmers had to return to barter trade and withdrew to subsistence production. Other explanations relate to institutional conditions (Davydova and Franks, 2006). During the privatisation process, politicians created confusion over individuals' rights to hold land and property shares. Hence, land reform was sporadic and varied across regions. State subsidies and other benefits initially offered to private farmers after independence ended abruptly. This caused problems regarding access to variable farm inputs and machinery. Private farmers often faced opposition from oblast (an administrative division analogous to a "state" or "province") and rural leaders, whose support was vital for farmers in gaining access to land and support programmes. The mind-set of the farmers or prospective farmers constituted another important institutional factor. The pioneering private farmers had to start from scratch and had little knowledge about running a farm. Moreover, for many years there were virtually no possibilities for farmers to enter into collaborations or benefit from other organisational assistance. Due to various support programmes in the last decade, there are now various organisational structures that are helping to make farmers much stronger.

The following section provides some background data on private farming in the Russian Federation, followed by a review of institutional conditions including, government policies, the norms within the farmers' minds and the norms that may result from the farmers' interaction with their business environment. 


\section{Development of private farming}

At the beginning of the transition from the Soviet regime, there was much optimism surrounding private farming in Russia. The Russian Association of Rural, Private Farmers and Agricultural Cooperatives (AKKOR) predicted in 1991 that by 2000 there would be about one million private farmers. The Russian government was more cautious, stating there would be about 350,000 private farmers by 2000 (Wegren, 2011). The World Bank (1992) reported “about 40 percent of agricultural land will be farmed privately by the end of 1995". However, others argued that the hyper-industrialisation of agricultural production had transformed active peasants into passive workers who were not capable of running farms. Hedlund (1990) stated that in a kolkhoz "those ... who dream of working individually, they just do not exist." Nevertheless, the number of private farmers increased rapidly during the first post-Soviet years. In early 1991 there had been about 4,400 private farms, this had approached 50,000 by the end of 1991 (Bruisch, 2007). The number of farms peaked at 285,000 in 1994-1995 and then gradually declined. By January 2000, their number stood at 260,000 but this declined to about 255,000 by 2006 (Sutherland, 2008; Wegren, 2011). After the introduction of support programmes in 2006, the number of private farms gradually increased again, to about 285,000 by 2009 . However, perhaps half of these registered farms were not operational (Wegren, 2011). Due to various support programmes, the number of private farms increased to over 300,000 by 2012 , but then sharply declined. The main reason for that decline seems to be that non-operational farms were dropped from the statistics. In 2014, the official number stood at 223,182 (Rosstat, 2015a,b,c).

The average farm size has increased since Soviet times. During the early 1990s it was slightly larger than the average household plot, but by 2005 it had risen to about 75 hectares. However, there was great variation between farms. In 1998, almost $57 \%$ of private farms managed less than 20 hectares, about $78 \%$ less than 50 hectares and just $6.4 \%$ farmed 100 hectares or more. Surprisingly, this distribution almost reflected the situation in 1992, although at that time private farms were much fewer in number (Wegren, 2000). By 2010 the average farm size had increased to about 85 hectares and since then it has continued to increase steadily reaching 162.8 hectares in 2014 (Rosstat, 2015a,b,c). While the number of private farmers has stagnated since 1995, their registered agricultural area has increased over the years. In 1992 about 2.5 million hectares were registered. This figure increased to around 12 million hectares by 1995, 15 million hectares in 2001 and 15.8 million hectares in 2009. However, not all agricultural land is farmed, although the ratio of actively farmed land to total agricultural land increased recently (Wegren, 2011). In line with the increase in registered land, the proportion of land farmed by private farmers increased over time. In 2011, about $12.5 \%$ of all agricultural land in Russia was managed by private farms (Uzun et al., 2014). Similarly, private farmers are now contributing more to the total agricultural output of the country. During the early 1990 s, their share was about $2 \%$. It gradually increased to about 3\% (2000) and then $6 \%$ in 2005 . By 
2010, it was more than $7 \%$. In 2014, it constituted $10 \%$ of total production, while the corporate farms contributed $48.6 \%$ and the household plot producers $41.4 \%$ (Rosstat, 2015a,b,c).

\section{Institutional conditions}

\section{Political forces}

While the first steps towards private farming were taken under Gorbachev at the end of the Soviet Union (Pallot and Nefedova, 2003), there was a strong political will to promote private farming during the first years after independence. The Yeltsin reforms were intended to establish a market economy in the agricultural sector. In place of collective and state farms, independent farmers relying on family labour were expected to make food production more efficient. This would lead to a decrease and, finally, abolition of the heavy food subsidies (Wegren, 2000). The slogan "Farmers will feed Russia" was widely communicated to the public. It was argued that continuing subsidies to collective and state farms would give them an unfair advantage and distort competition. It was also argued that if these subsidies were abolished, the large farms would have to cut employment and the laid-off workers would take up private farming. It was believed that if there were funds for subsidies at all, these should be targeted at private farms. It was anticipated that private farms of between 25 and 50 hectares would develop and that these would be the basis for an internationally competitive agricultural sector and ensure farmers an income level comparable to that in non-agricultural sectors (Deininger, 1995).

The land reform included two major components, namely private ownership of land and the division of land into private farms (Lerman, 1998). Concerning privatisation of land, the government chose 'share-based' land distribution as opposed to the 'plot-based' system previously practised in most Central and Eastern European countries (Visser et al., 2014). The transfer of ownership rights involved two steps. First, working and retired workers on the collective and state farms received land certificates. The entitlements to land were of a certain size, but they did not establish a direct link between a specific plot of land and a certain individual. On average, worker-members of the Soviet farms were each entitled to 14-16 hectares (Herrold-Menzies, 2009). However, these shares were 'paper-shares' and it took a second step requiring effort and finance to get these transferred into ownership titles to specific land plots (Rozelle and Swinnen, 2004).

In addition to using their own land shares, prospective farmers could rely on a 'land fund' in their respective region. Under federal legislation, regional governments were required to assign about $10 \%$ of the land formerly used by collective and state farms as a reserve for redistribution. This reserve land was required to be of average natural fertility, but it was generally less fertile than the land remaining in the collective and state farms and it was relatively far from the villages (Sazonov and Sazonova, 2005). During the first years after independence in particular, the most common source of land for private farmers was allocation of reserve land. In the following years, the most common method for creating private farms was the withdrawal of land shares for a land plot in kind. In general, the 
prospective farmers tried to combine the shares of several family members and leased land shares from other shareholders (Prosterman, 1997).

In principle, not just owners of land shares but all Russian citizens - urban or rural dwellers over 18 years of age - were eligible to receive a free land plot, up to established raion norms (a raion is an administrative unit under an oblast, analogous to a "district") in order to start a private farm. For individuals who did not want to become private farmers, land plots for other agricultural uses such as household plots were available free until December 1993; after that date they were free to rural residents but sold to urban residents. Since food was relatively expensive, it was assumed that a large share of rural and urban people would take land to secure their own household needs (Wegren, 1998). Indeed, almost all households made use of this offer. The number of household plot cultivators increased from about 14 million in 1990 (at that time mostly rural households) to about 36.6 million during the mid-2000s (of which 22.8 million were rural) (Uzun, 2008; Uzun et al., 2014).

Nevertheless, establishing a private farm was not an easy option. Prospective candidates had to apply to local authorities and get registered. Private farmers, like large-scale corporate farms, are registered as 'legal entities' whose income from food sales is taxed (Wegren, 2014).

The already limited government support for private farming during the first years after independence soon disappeared. In principle, private farmers enjoyed the same type of support as other agricultural enterprises. However, in reality the agricultural policies were biased in favour of large farms. Private farmers knew less about how to apply for regional and federal programmes. Hence, almost all credits and subsidies ended up with the large farms (Sazonov and Sazonova, 2005). The support for largescale corporate farms didn't cease, since even in difficult economic times, local and regional administrations tried to support the operation of large farms, through tax concessions and limited financial support, to ensure employment for most agricultural workers. Most local and regional officials were convinced that large-scale farming was the best form of agricultural production (Wegren, 2011).

In the early 2000s, the official agricultural policy de-emphasised the relevance of private farms and instead prioritised the revival of food production on large farms. The policy in the early 1990s to attempt to break up large farms was regarded as a mistake and large farms were once again viewed as being superior to smaller units. This policy was further accentuated when in August 2008, core agrofood businesses (including large farms) were included in the registry of 'Systemic Companies' ('National Champions') considered to be most important for national defence and state security (Matyukha et al., 2015). However, on the other side, agricultural development programmes since the mid-2000s aimed at supporting all types of producers regardless of their size and legal registration. Since then, policy statements repeatedly make reference to the growing significance of private farmers for food production. State funding in support of private farmers has increased and the farmers have become eligible for an array of technical assistance under the state support programmes (Wegren, 
2011). However, as in the earlier period, private farmers receive significantly less financial support than large farms. For example, in 2013 private farmers received 8.5 billion roubles $(<5 \%)$ in government support, from a total budget of 188 billion roubles. With respect to subsidised credits, the application process is quite cumbersome and, due to lack of collateral, the creditworthiness of private farmers is low. The few who received subsidised credit often faced difficulties in making their repayments on time (Wegren, 2014).

\section{Mind-set of private farmers}

The first private farmers had some specific characteristics. While it was anticipated that collective and state farm workers would become private farmers, most of these had no desire to farm individually. Those who showed some interest refrained, mainly because of lack of resources and the relatively bad experience of private farmers in their region (Sutherland, 2008; Golovina et al., 2013). Every adult Russian citizen could apply for agricultural land, while the stipulation of 'specialised agricultural knowledge or past specialist training' was often not enforced. Thus, in 1990-91 the bulk of new farmers had no agricultural experience and in fact about two-thirds of the new private farmers came from the city. This pattern changed during the next two years. By the end of 1993, more than $85 \%$ of private farmers had a rural background (Wegren, 1998). Nevertheless, there still appears to be a difference as regards attitudes and priorities between remaining farm-enterprise employees and those who took up private farming. Based on interviews conducted during the early 1990s, Lerman (1998: 327) observed that both groups are "basically the same human material..., but ..., on the whole, farmers are ... more optimistic than employees of collective enterprises." In an analysis of farm managers and private farmers, Wegren (2000) reported that both groups had, on average, a higher level of education and a lower age than farm employees. Both factors seem to "correlate with a positive orientation toward reform and willingness to undertake entrepreneurial activities" (Wegren, 2000: 240). In a survey in Belgorod region in 2013, Efendiev and Sorokin (2013) analysed private farmer attitudes. They observed that farmers preferred working on their own land and making a living from it. They found a positive change in attitudes towards family entrepreneurship and individualism compared with a similar survey in 2000. This attitude change might reflect the general positive economic development in Russia up to 2014. The authors suggested "that long claimed communality of Russian rural dwellers ... may be partly disappeared while individualism and entrepreneurial activity are growing rapidly..." (Efendiev and Sorokin, 2013: 111).

\section{Organisations of private farmers}

Up to the mid-2000s there was almost no formalised collaboration among private farmers. One reason might be that "the 'communist legacy' had left farmers doubtful regarding any organized cooperation due to their experience of 'enforced cooperation' during the socialist era" (Hagedorn, 2014: 557). However, there was informal collaboration among private farmers. Gardner and Lerman (2006) 
concluded that about three-quarters of farmers collaborate, particularly when it comes to agricultural extension and machinery exchanges. Informal collaboration often involves a few farm households (Prosterman et al., 1997; Davydova and Franks, 2006). Hence, a growing number of rural organisations are protecting the interests of the rural population and creating a favourable climate for agricultural entrepreneurship (Mamonova and Visser, 2014). One reason seems to be a focus of the Russian government on the development of private farmers and co-operatives. One objective was to provide credit through farmers' co-operatives. Other collaborative arrangements concern machinery pools, marketing, financial services, information exchange and input supplies.

By October 2014, there were 6,568 farmer co-operatives registered with the Ministry of Agriculture. Of these 1,166 focused on input supplies and marketing activities; 1,780 on credit activities and 998 on processing of agricultural products, while 2,268 did not specify their activities. They have in total around 200,000 members. However, about one-third of the co-operatives are not operational and it is unclear to what extent the remainder are supporting their members (Uzun et al., 2014; Ministry of Agriculture, 2015). AKKOR is a hybrid between a lobbying organisation protecting the private farmers' interests and a public administration. It was established in a top-down manner by the Soviet Ministry of Agriculture in 1990. With the declining support for private farming the influence of AKKOR diminished, but lately it seems to have become more relevant, perhaps because of its links to the strongest political party, United Russia. It claims to represent about 93,000 members. It is organised in 65 regions of Russia and comprises more than 642 raion-level organisations (Wegren, 2011; AKKOR, 2015).

For private farming to be successful, social support is essential, not only within the family but also within networks of farmers (Sutherland, 2008). Networks compensate for economic insecurity. During the post-Soviet period, private farmers had to draw on informal ties to gain access to resources (Small, 2007). On the basis of interviews with entrepreneurs in Russia, Batjargal (2003) stressed the importance of having acquaintances with large financial resources. Other authors refer to a specifically Russian network form (blat), which involves actors granting favours to one another (Estrin et al., 2005). Thus, the entrepreneurial firms in Russian agriculture benefit by developing their own institutional conditions. The entrepreneurs may be able to establish networks to withstand the dominating institutional structures. Such entrepreneurial institutions are most likely to evolve as trustful collaborations that the entrepreneurs have with each other. The individuals' sets of financial and physical capital are thus extended with social capital.

\section{Conclusions}

Three categories of institutional drivers behind the development of Russian private farming have been identified and reviewed - political forces, farmers' values and desires and organisational structures. These factors reflect rules and norms within political and social spheres, thus directing the actions and 
interaction of people. The political system has at times supported private farming, but in other periods has been less sympathetic. The ensuing uncertainties have impaired the development of Russian private farming. There are, however, indications of change, perhaps related to the official farmers' organisation's link to the ruling political party. The private farmers in Russia are becoming increasingly business orientated. Evidence suggests that private farming is again expanding, for example increasing its share of national agricultural production, but it is far from being the dominant type of farm organisation. The development of a more entrepreneurial spirit can be attributed to both formal and informal organisations in rural areas.

\section{References}

AKKOR (Russian Association of Rural, Private Farmers and Agricultural Co-operatives) (2015). (http://www.akkor.ru/analitika-i-obzory-27.html) (29 October 2015).

Batjargal. B. (2003). Social capital and entrepreneurial performance in Russia: A longitudinal study. Organizational Studies, 24(4), 535-556.

Binswanger, H., Deininger, K. and Feder, G. (1995). Power, distortions, revolt and reform in agricultural land relations. in: Behrman, J. and Srinivasan, T.N. (eds): Handbook of Development Economics Vol. III. Elsevier. New York, NY, pp. 2659-2772.

Bruisch, K. (2007). Entwicklungstendenzen landwirtschaftlicher Familienbetriebe in Russland seit 1990, (Discussion Paper 108). IAMO, Halle (Saale).

Davydova, I., and Franks, J.R. (2006). Responses to agrarian reform in Russia: Evidence from Novosibirsk oblast. Journal of Rural Studies, Vol. 22, No. 1, pp 39-54.

Deininger, K. (1995). Collective agricultural production: A solution for transition economies? World Development, Vol. 23, No. 8, pp 1317-1334.

Eastwood, R., Lipton, M. and Newell, A. (2010). Farm size. in: Pingali, P.L. and Evenson, R.E. (eds.) Handbook of Agricultural Economics. Vol. 4, Amsterdam, North-Holland, pp. 3323-3397.

Efendiev, A., and Sorokin, P. (2013). Rural social organization and farmer cooperatives development in Russia and other emerging economies: Comparative Analysis. Developing Country Studies, Vol. 3, No. 14, pp 106-115.

Estrin, S., Meyer, K.E., and Bytchkova, M. (2005). Entrepreneurship in transition economies. in:

Basu, A., Casson, M., Wadeson, N. and Yeung, B. (eds.). The Oxford Handbook of Entrepreneurship. Oxford University Press, Oxford.

Gardner, B., and Lerman, Z. (2006). Agricultural cooperative farming in the transition from socialist collective farming. Journal of Rural Cooperation, Vol. 34, No. 1, pp. 1-18. 
Golovina, S., Nilsson, J., and Wolz, A. (2013). Members' choice of production co-operatives in the Russian agriculture. Post-Communist Economies, Vol. 25, No. 4, pp 465-491.

Hagedorn, K. (2014). Post-socialist farmers' cooperatives in Central and Eastern Europe. Annals of Public and Cooperative Economics, Vol. 85, No. 4, pp 555-577.

Hedlund, S. (1990). Family plots as a system stabilizer. in: Wädekin, K.-E. (ed.): Communist Agriculture: Farming in the Soviet Union and Eastern Europe. Routlegde, London and New York, pp. 215-229.

Herrold-Menzies, M. (2009). The post-collective village: A tale of two transitions. World Development, Vol. 37, No. 1, pp 232-241.

Hodgson, G.M. (2006). What are institutions? Journal of Economic Issues, Vol. 60, No. 1, pp. 1-25. Ioffe, G., Nefdova, T. and De Beurs, K. (2012). Land abandonment in Russia: A case study of two regions. Eurasian Geography and Economics, Vol. 53; No. 4, pp. 527-549.

Lerman, Z. (1998). Does land reform matter? Some experiences from the former Soviet Union. European Review of Agricultural Economics, Vol. 25, No. 3, pp 307-330.

Lerman, Z. (ed.) (2008) Russia's Agriculture in Transition. Lexington Books, Lanham MD. Matyukha, A., Voigt, P., and Wolz, A. (2015). Agro-holdings in Russia, Ukraine and Kazakhstan: temporary phenomenon or permanent business form? Farm-level evidence from Moscow and Belgorod regions. Post-Communist Economies, Vol. 27, No. 3, pp 370-394.

Ministry of Agriculture (2015). Figures on agricultural consumer (service) cooperatives http://kurganstat.gks.ru (21 October 2015).

Pallot, J., and Nefedova, T. (2003). Trajectories in people's farming in Moscow oblast during the postsocialist transformation. Journal of Rural Studies, Vol. 19, No. 3, pp 345-362.

Pollak, R.A. (1985). A transaction cost approach to families and households. Journal of Economic Literature, Vol. 23, No. 2, pp. 581-608.

Prosterman, R.L., Mitchell, R.G., and Rorem, B.J. (1997). Prospects for family farming in Russia. Europe-Asia Studies, Vol. 49, No. 8, pp 1383-1407.

Rosstat (Federal State Statistics Service) (2004). Russian Statistical Yearbook 2003. (Российский статистический ежегодник 2003 г.)

http://www.gks.ru/bgd/regl/b03_13/IssWWW.exe/Stg/d030/i030880r.htm (11 January 2016).

Rosstat (2015a). Social-economic indicators of the Russian Federation, 1991-2014. (Социальноэкономические показатели Российской Федерации в 1991-2014 гг.) 
http://www.gks.ru/wps/wcm/connect/rosstat_main/rosstat/ru/statistics/publications/catalog/doc_12707 07126016 (11 January 2016).

Rosstat (2015b). Small and medium entrepreneurship in Russia. (Малое и среднее предпринимательство в России 2003,...,2014)

http://www.gks.ru/bgd/regl/B03 47/IssWWW.exe/Stg/d010/i010590r.htm http://www.gks.ru/bgd/regl/b06_47/IssWWW.exe/Stg/2-01.htm (11January 2016).

Rosstat (2015c). Main indicators of agriculture in Russia. (Основные показатели сельского хозяйства в России $2005, \ldots, 2014)$

http://www.gks.ru/wps/wcm/connect/rosstat_main/rosstat/ru/statistics/publications/catalog/doc_11400 9 (11 January 2016).

Rozelle, S., and Swinnen, J.F.M. (2004). Success and failure of reform: Insights from the transition of agriculture. Journal of Economic Literature, Vol. 42, No. 2, pp 404-456.

Sazonov, S., and Sazonova, D. (2005). Development of peasant farms in Central Russia. Comparative Economic Studies, Vol. 47, No. 1, pp 101-114.

Small, A.-L. (2007). East Meets West: Utilising western literature to conceptualise Post-Soviet agrarian change. Journal of Peasant Studies, Vol. 34, No. 1, pp 29-50.

Schmitt, G. (1993). Why collectivization of agriculture in socialist countries has failed: A transaction cost approach. in: Csaki, C. and Y. Kislev (eds.). Agricultural Cooperatives in Transition. Boulder, Westview Press, pp. 143-159.

Sutherland, L.A. (2008). Post-Soviet agricultural employment: A case study of employee incentives in Krasnodar Territory, Russia. Journal of Peasant Studies, Vol. 35, No. 3, pp 369-389.

Uzun, V. (2008). Large and small business in Russian agriculture. in: Lerman, Z. (ed.): Russia's Agriculture in Transition. Lexington Books, Lanham MD, pp 11-56.

Uzun, V., Saraikin, V., Gataulina, E., Shagayda, N., Yanbykh, R., Mary, S., and Gomez y Paloma, S. (2014). Prospects of the farming sector and rural development in view of food security: The case of the Russian Federation. EU Publication Office (JRC-ITPS). Luxembourg,

Visser, O., Spoor, M., and Mamonova, N. (2014). Is Russia the emerging global 'breadbasket'? Recultivation, agroholdings and grain production. Europe-Asia Studies, Vol. 66, No. 10, pp 1589-1610. Wegren, S.K. (1998). The conduct and impact of land reform in Russia. In: Wegren, S.K. (ed.) Land Reform in the Former Soviet Union and Eastern Europe. Routledge, London/New York, pp 3-34. Wegren, S.K. (2000). Socioeconomic transformation in Russia: Where is the rural elite? Europe-Asia Studies, Vol. 52, No. 2, pp 237-271. 
Wegren, S.K. (2011). Family farming in Russia: An emerging success? Post-Soviet Affairs, Vol. 26, No. 3, pp 211-240.

Wegren, S.K. (2014). The Russian food embargo and food security: can household production fill the void? Eurasian Geography and Economics, Vol. 55, No. 5, pp 491-513.

World Bank (1992). Food and Agricultural Policy Reforms in the Former USSR: An Agenda for the Transition. (Studies of Economies in Transformation, Paper No. 1), Washington, DC.

Table 1 Main indicators of private farming in the Russian Federation (1991-2014).

\begin{tabular}{lcccccc}
\hline Private farms & $\mathbf{1 9 9 1}$ & $\mathbf{1 9 9 5}$ & $\mathbf{2 0 0 0}$ & $\mathbf{2 0 0 5}$ & $\mathbf{2 0 1 0}$ & $\mathbf{2 0 1 4}$ \\
\hline Number & 4,400 & 280,100 & 261,700 & 257,400 & 285,000 & 223,200 \\
Average farm size (hectares) & 41 & 43 & 58 & 75 & 85 & 162.8 \\
$\begin{array}{l}\text { Share of national agricultural } \\
\text { production (\%) }\end{array}$ & $<1$ & 1.9 & 3.2 & 6.1 & 7.2 & 10.0 \\
\hline
\end{tabular}

Source: Rosstat, 2004, 2015a, b, c. 